\title{
Improving identification of pulmonary embolism-related out-of-hospital cardiac arrest to optimize thrombolytic therapy during resuscitation
}

\author{
François Javaudin ${ }^{1,2^{*}}$ (D) Jean-Baptiste Lascarrou ${ }^{3}$, Hyacinthe Esquina ${ }^{1}$, Valentine Baert ${ }^{4}$, Hervé Hubert ${ }^{4}$, \\ Brice Leclère ${ }^{2,5}$ on behalf of GR-RéAC
}

Keywords: Out-of-hospital cardiac arrest, Thrombolytic therapy, Pulmonary embolism, Cardiopulmonary resuscitation

Pulmonary embolism (PE) is responsible for $\sim 3 \%$ of Out-of-Hospital Cardiac Arrest (OHCA) and is associated with unfavorable prognoses [1]. We have recently shown that thrombolysis during resuscitation was associated with a better survival in the event of a proven pulmonary embolism [2]. The challenge is thus to identify, from the beginning of resuscitation, PE-related OHCA in order to deliver the proper treatment to the patient. This issue is highlighted by the premature stoppage of the TROICA trial [1], which showed no benefit of using thrombolysis in medical cardiac arrests. Our aim was to identify the factors associated with PE-related OHCA.

We selected adults from the French National OHCA Registry, admitted to the hospital. This registry and the OHCA management by a mobile medical team have been previously described [3]. The present study was approved by the French Advisory Committee on Information Processing in Health Research. It was approved as a medical assessment registry without a requirement for patient consent.

We assessed characteristics associated with PE-related OHCA with a univariable analysis $\left(\chi^{2}\right.$ test, Fisher's exact test or Student's $t$ test). A multivariate logistic regression model was then developed to identify the factors associated with $\mathrm{PE}$ with a $P$ value $<0.20$. Statistical analyses were performed using $\mathrm{R}$ software v3.6.1.

From July 2011 to March 2018, 14,253 patients were admitted to the hospital. We excluded OHCAs whose cause was obvious from the beginning of the resuscitation $(n=$ $2341)$ or where data was incomplete $(n=1150)$. The final analysis included 10,402 subjects. Two hundred sixty subjects $(2 \%)$ were diagnosed with PE upon hospital admission by computed tomography pulmonary angiography (CTPA) or echocardiogram. The results of the univariate and multivariate analyses are presented in Table 1 . The prevalence of PE was $22 \%$ among the population with nonshockable rhythm and history of thromboembolism.

\footnotetext{
* Correspondence: francois.javaudin@chu-nantes.fr

${ }^{1}$ Department of Emergency Medicine, University Hospital of Nantes, Nantes, France

${ }^{2}$ Microbiotas Hosts Antibiotics and bacterial Resistances (MiHAR), University

of Nantes, Nantes, France

Full list of author information is available at the end of the article
} 
Table 1 Factors associated with OHCA caused by PE

\begin{tabular}{|c|c|c|c|c|c|}
\hline & $\begin{array}{l}\text { PE-related OHCA } \\
(n=260)\end{array}$ & $\begin{array}{l}\text { Other etiologies } \\
(n=10,142)\end{array}$ & Chi $^{2}$ Pearson $p$ & $\begin{array}{l}\text { Multivariate logistic regression } \\
\text { adjusted odds ratio }[95 \% \mathrm{Cl}]\end{array}$ & $p$ \\
\hline Female, $n(\%)$ & $139(53.5)$ & $3204(31.6)$ & $<0.001$ & $2.0[1.5-2.5]$ & $<0.001$ \\
\hline Age $<50$ y, $n(\%)$ & $67(25.8)$ & $2101(20.7)$ & 0.048 & $1.5[1.1-2.0]$ & 0.01 \\
\hline Absence of known heart disease, $n(\%)$ & $170(65.4)$ & $5790(57.1)$ & 0.008 & $1.3[1.0-1.7]$ & 0.05 \\
\hline History of respiratory disease, $n(\%)$ & $35(13.4)$ & $1350(13.3)$ & 0.94 & & \\
\hline History of diabetes, $n$ (\%) & $34(13.1)$ & $1407(13.9)$ & 0.71 & & \\
\hline Absence of known comorbidities, $n$ (\%) & $43(16.5)$ & $1431(14.1)$ & 0.27 & & \\
\hline History of thromboembolism, $n$ (\%) & $8(3.1)$ & $41(0.4)$ & $<0.001^{a}$ & $6.4[2.7-13.5]$ & $<0.001$ \\
\hline History of cancer, $n(\%)$ & $25(9.6)$ & $535(5.3)$ & 0.002 & $1.6[1.0-2.3]$ & 0.04 \\
\hline Initial nonshockable, No. (\%) & $245(94.2)$ & $5947(58.6)$ & $<0.001$ & $10.4[6.4-18.4]$ & $<0.001$ \\
\hline
\end{tabular}

${ }^{\mathrm{a}}$ Fisher's exact test

$P E$ pulmonary embolism, OHCA out-of-hospital cardiac arrest

These two factors had a sensitivity of 22\% (95\% CI [10-39]), a specificity of $98 \%$ (95\% CI [97-98]) to detect PE. When an age limitation of $<50$ years was added to these two factors, the probability of PE was $44 \%$ (Fig. 1).

In summary, this study found two factors strongly associated with PE: initial nonshockable rhythm and prior thromboembolism. These factors had already been described by Bouguoin et al. [4] as the two major factors associated with the diagnosis of PE-related OHCA. Moreover, in our study, young age was a risk factor for $\mathrm{PE}$, and this population has a lower risk of major bleeding in the case of thrombolysis, as shown in the PEITHO trial (lower risk if $\leq 75$ years) [5].

Our study had some limitations such as the lack of completeness of data which may have resulted in the selection of the population not being completely exhaustive. Moreover, the method of confirming PE either by CTPA or echocardiogram was not known for each patient, which may have underestimated the number of PE cases due to the lack of sensitivity for the ultrasound. In addition, autopsy results were not included in the data. Finally, we were unable to include subjects who died on site and were not admitted to hospital because of a lack of confirmation of the etiology of OHCA.

In conclusion, we recommend that for cases of OHCA for which a cause is not obvious, suspect a pulmonary embolism if the initial rhythm is nonshockable and there is a medical history of thromboembolism. In accordance with the guidelines of the American Heart Association (AHA) [6], these subjects should be treated by thrombolysis during resuscitation, especially when they are young.

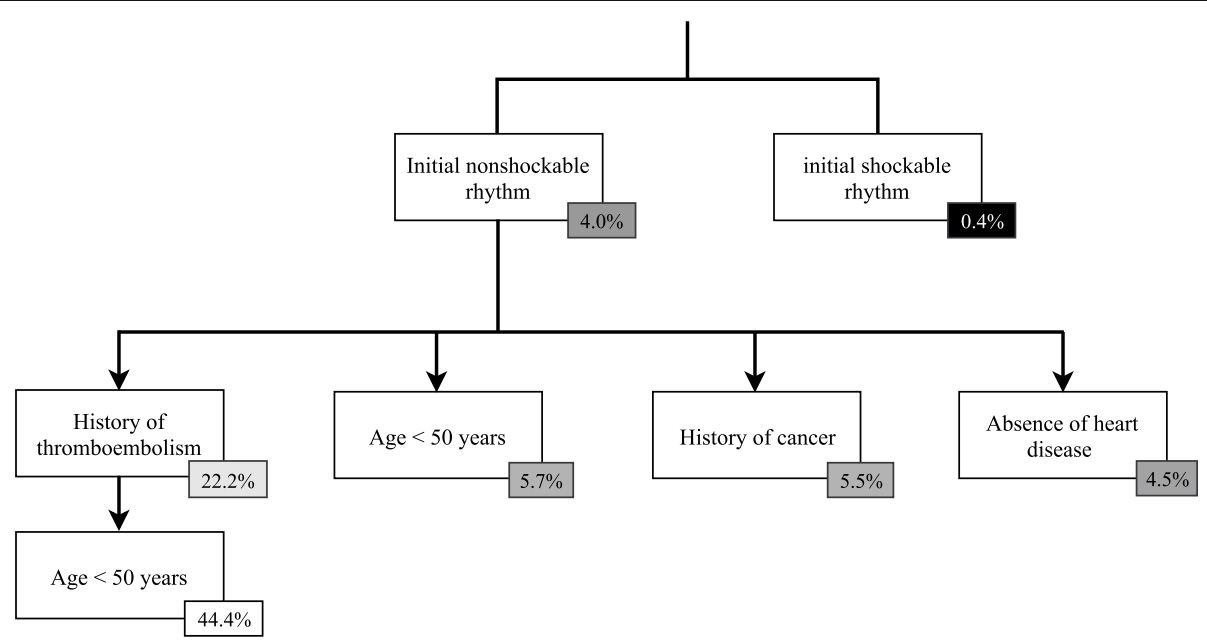

Fig. 1 Tree representation of the frequency of pulmonary embolism according to risk factors 


\section{Abbreviations}

OHCA: Out-of-hospital cardiac arrest; PE: Pulmonary embolism; RéAC: French National OHCA Registry; 95\% Cl: 95\% confidence interval; CTPA: Computed tomography pulmonary angiography; AHA: American Heart Association

\section{Acknowledgements}

We thank all the prehospital emergency medical service units in France investigated in RéAC.

\section{Authors' contributions}

FJ and BL developed the analysis plan. FJ undertook the main analysis with supervision from BL. FJ wrote the first draft of the paper, with all other authors making important critical revisions. All authors have read and approved the final version of the manuscript.

\section{Funding}

The RéAC registry is supported by the French Society of Emergency Medicine (SFMU), a patient foundation-Fédération Française de Cardiologie, the Mutuelle Générale de l'Education Nationale (MGEN), the University of Lille, and the Institute of Health Engineering of Lille. The authors declare that the funding sources had no role in the conduct, analysis, interpretation, or writing of this manuscript.

\section{Availability of data and materials}

All data that were collected where listed in an anonymous database. The dataset is not available but can be requested from the corresponding author.

\section{Ethics approval and consent to participate}

The present study was approved by the French Advisory Committee on Information Processing in Health Research and the French National Data Protection Commission (authorization no. 910946). It was approved as a medical assessment registry without a requirement for patient consent.

\section{Consent for publication}

The study was approved as a medical assessment registry without a requirement for patient consent.

\section{Competing interests}

The authors declare that they have no competing interests.

\section{Author details}

${ }^{1}$ Department of Emergency Medicine, University Hospital of Nantes, Nantes, France. ${ }^{2}$ Microbiotas Hosts Antibiotics and bacterial Resistances (MiHAR), University of Nantes, Nantes, France. ${ }^{3}$ Medical Intensive Care Unit, University Hospital of Nantes, Nantes, France. ${ }^{4}$ Public Health Department EA 2694, Lille University Hospital, University of Lille, Lille, France. ${ }^{5}$ Department of Epidemiology and Medical Evaluation, University Hospital of Nantes, Nantes, France.

Received: 4 November 2019 Accepted: 13 November 2019

Published online: 13 December 2019

\section{References}

1. Böttiger BW, Arntz H-R, Chamberlain DA, et al. Thrombolysis during resuscitation for out-of-hospital cardiac arrest. N Engl J Med. 2008;359(25): 2651-62.

2. Javaudin F, Lascarrou J-B, Le Bastard Q, et al. Thrombolysis during resuscitation for out-of-hospital cardiac arrest caused by pulmonary embolism increases 30-day survival: findings from the French National Cardiac Arrest Registry. Chest. 2019. https://doi.org/10.1016/j.chest.2019. 07.015 .

3. Javaudin F, Desce N, Le Bastard Q, et al. Impact of pre-hospital vital parameters on the neurological outcome of out-of-hospital cardiac arrest: results from the French National Cardiac Arrest Registry. Resuscitation. 2018; 133:5-11.

4. Bougouin W, Marijon E, Planquette $B$, et al. Factors associated with pulmonary embolism-related sudden cardiac arrest. Circulation. 2016; 134(25):2125-7.

5. Meyer G, Vicaut E, Danays T, et al. Fibrinolysis for patients with intermediate-risk pulmonary embolism. N Engl J Med. 2014;370(15):1402-11.
6. Link MS, Berkow LC, Kudenchuk PJ, et al. Part 7: Adult Advanced Cardiovascular Life Support: 2015 American Heart Association Guidelines Update for Cardiopulmonary Resuscitation and Emergency Cardiovascular Care. Circulation. 2015;132(Suppl 2):S444-64.

\section{Publisher's Note}

Springer Nature remains neutral with regard to jurisdictional claims in published maps and institutional affiliations.

\section{Ready to submit your research? Choose BMC and benefit from:}

- fast, convenient online submission

- thorough peer review by experienced researchers in your field

- rapid publication on acceptance

- support for research data, including large and complex data types

- gold Open Access which fosters wider collaboration and increased citations

- maximum visibility for your research: over $100 \mathrm{M}$ website views per year

At BMC, research is always in progress.

Learn more biomedcentral.com/submissions 